\title{
Harmful algal bloom toxins protect bivalve populations from sea otter predation
}

\author{
Rikk Kvitek ${ }^{*}$, Carrie Bretz \\ Earth Systems Science and Policy, California State University Monterey Bay, 100 Campus Center, \\ Seaside, California 93955, USA
}

\begin{abstract}
We demonstrate how harmful algal bloom (HAB) toxins can mediate the strength of consumer-prey interactions, and thus ecosystem level patterns and processes, by altering the foraging behavior of a keystone marine predator (sea otter Enhydra lutris). Our approach was to compare sea otter foraging behavior, diet, prey abundance and paralytic shellfish poisoning toxins (PSPT) across a range of sites within the Inside Passage of southeast Alaska recently occupied by sea otters. Sea otters in southeast Alaska modified their foraging behaviors depending on concentrations of PSPT in bivalve prey, especially their preferred prey, butter clams Saxidomus giganteus. At sites of intermediate prey toxicity (200 to $500 \mathrm{\mu g}$ saxitoxin [STX] eq $\cdot 100 \mathrm{~g}^{-1}$ ), otters continued to forage on butter clams while discarding the most toxic body parts. At highly toxic sites (prey toxicity $>500 \mu \mathrm{g} \mathrm{STX} \mathrm{eq} \cdot 100 \mathrm{~g}^{-1}$ ) otters avoided butter clams and other large and abundant but toxic bivalve prey, and consumed smaller and/or less abundant non-toxic species. Butter clams were larger and more abundant in highly toxic feeding areas, supporting the hypothesis that PSPT toxicity provides a refuge from sea otter predation.
\end{abstract}

KEY WORDS: Chemical defense - Paralytic shellfish poisoning $\cdot$ Harmful algal blooms $\cdot$ Enhydra lutris $\cdot$ Butter clam $\cdot$ Bivalves $\cdot$ Alaska

Resale or republication not permitted without written consent of the publisher

\section{INTRODUCTION}

Harmful algal blooms (HABs) pose a serious threat to public health and local economies (Culotta 1992, Shumway \& Cembella 1993, Anderson 1997, Bates 1997, Anderson et al. 2000, Van Dolah 2000, Van Dolah et al. 2001), but can also exert a strong influence on marine communities, as highly lethal toxins produced by many HAB species move through and accumulate in marine food chains (Paul 1992a,b, Smayda 1992, 1997, Turner \& Tester 1997, Landsberg 2002). HAB toxins have been linked to mass mortalities of highlevel marine predators (fish, birds, whales, pinnipeds) (Keyes 1965, Coulson 1968, Armstrong 1978, White 1980, 1981, Nisbet 1983, Geraci et al. 1989, Work et al. 1993, Sierra-Beltrán et al. 1997, Scholin et al. 2000) and have been shown to influence the foraging behavior and prey preference of fish, avian and mammalian predators in controlled feeding experiments (Kvitek 1991a,b, Kvitek et al. 1991, DeGange \& Beitler 1991).
These results suggest that HAB toxins retained by prey may deter or exclude these ecologically important predators from areas affected by HABs and, thereby, alter ecosystem structure and function (White 1980, Kvitek 1991a,b, 1993, Kvitek \& Beitler 1991, Kvitek et al. 1991, 1993). Here we utilize the recent expansion of southeast Alaskan sea otters Enhydra lutris (Agler et al. 1995) (Fig. 1) into areas known to contain large and chronically toxic populations of their preferred bivalve prey Saxidomus giganteus (hereafter butter clams) (Nishitani \& Chew 1988, Kvitek et al. 1991, 1993, Kvitek \& Oliver 1992) to test this hypothesis.

Well documented as a keystone predator in both rocky and softbottom habitats throughout their range in the northeastern Pacific (Duggins et al. 1989, Kvitek \& Oliver 1992, Kvitek et al. 1992, Estes \& Duggins 1995, Steinberg et al. 1995, Estes et al. 1998), sea otters limit the size and distribution of butter clams in habitats where this species otherwise tends to dominate bivalve communities (Kvitek \& Oliver 1992, Kvitek et 


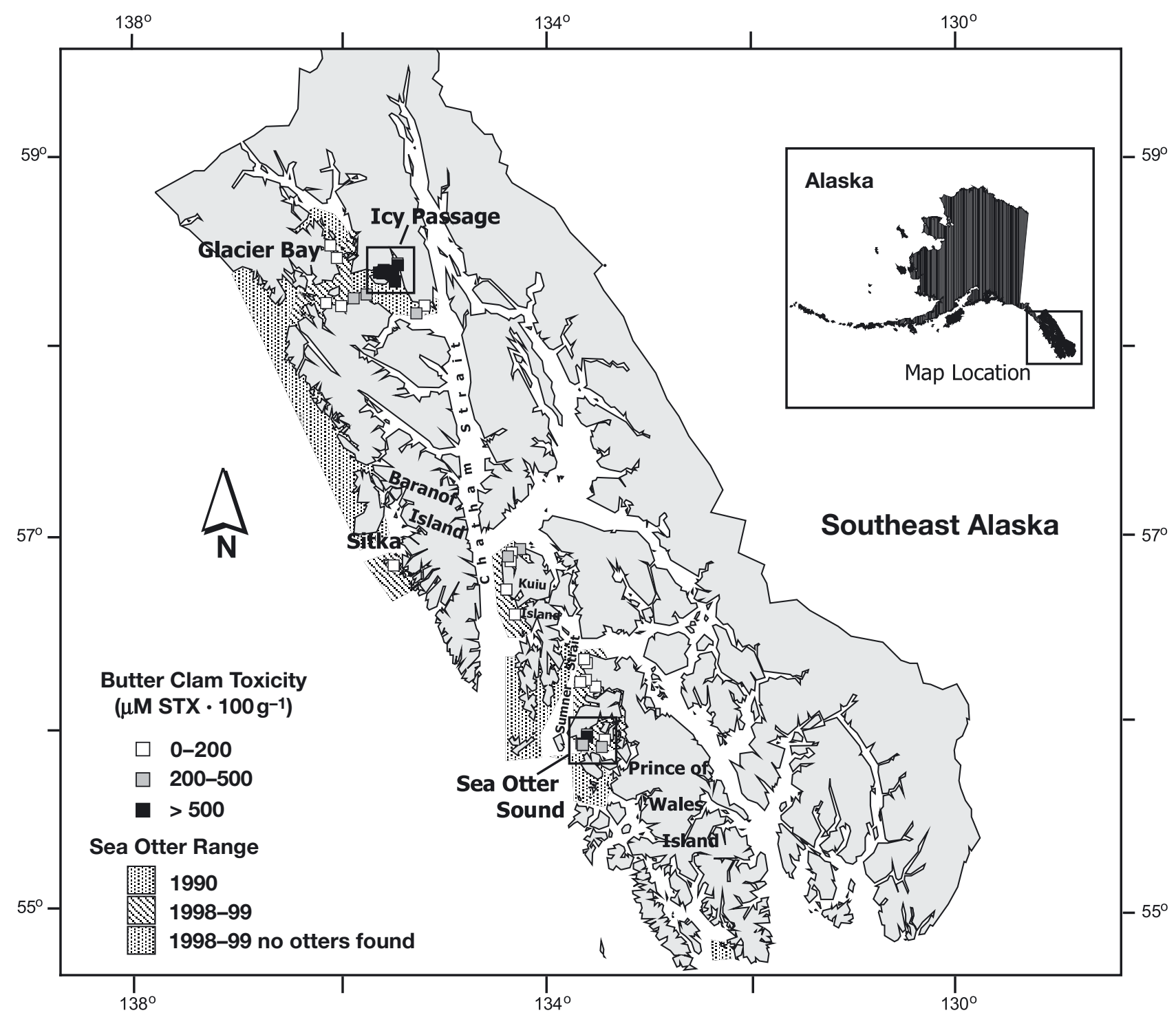

Fig. 1. Enhydra lutris and Saxidomus giganteus. Map of SE Alaska showing areas of sea otter range expansion from 1990 (Kvitek \& Oliver 1992) to 1999 that were used as general study areas for this project, as well as the distribution of butter clam paralytic shellfish poisoning toxins (PSPT) toxicity values found at the specific study sites within these general study areas. Also shown are areas that were surveyed by small boats during the 1998 and 1999 field seasons, but in which no sea otters were found

al. 1992). Butter clams, however, can accumulate and retain high concentrations of saxitoxin (STX) and its analogues for >1 yr (Quayle 1969, Shumway 1990, Bricelj \& Shumway 1998), also known as paralytic shellfish poisoning toxins (PSPT), the most lethal and widespread HAB toxin (Van Dolah 2000). Consequently, PSPT concentrations in many butter clam populations along the Inside Passage of Southeastern Alaska chronically exceed USFDA (U.S. Food and Drug Administration) quarantine concentrations $\left(80 \mu \mathrm{g} \mathrm{STX} \mathrm{eq} \cdot 100 \mathrm{~g}^{-1}\right)$ (Nishitani \& Chew 1988, Van Dolah 2000). Prior to 1991, sea otters in southeast Alaska were found primarily along the outer coast, where they preyed preferentially upon butter clams with no history of PSPT toxicity (Fig. 1) (Kvitek 1991b, Kvitek et al. 1991, Kvitek \& Oliver 1992). In captive studies, sea otters altered their feeding behavior when given butter clams containing $>226 \mu \mathrm{g}$ STX eq $\cdot 100 \mathrm{~g}^{-1}$, by either discarding the more highly toxic siphons, or simple cessation of feeding (Kvitek et al. 1991). In this study, we determined the threshold concentrations of PSPT avoided by freeranging sea otters, and how this avoidance translated to differences in the prey population status.

The strategy for evaluating whether PSPT affects the foraging behavior and distribution of sea otters was to determine: (1) whether or not the expanding southeast Alaskan sea otter population had begun to occupy 
Inside Passage sites where butter clams contain biologically significant concentrations of PSPT, and (2) if so, whether the sea otters at these 'toxic' sites either shifted their diet away from their preferred butter clam prey to alternate non-toxic species, or continued to eat butter clams, while discarding the most toxic body parts. Our approach was to compare sea otter foraging behavior, diet, prey abundance and PSPT toxicity across a range of sites within the Inside Passage of southeast Alaska recently occupied by sea otters and likely to provide a broad gradient of butter clam toxicity (Fig. 1). Our expectation, based on prior captive feeding and sea otter/toxic prey distribution studies (Kvitek et al. 1991, 1993), was that these predicted changes should begin to occur at prey toxicity concentrations of between 150 and $225 \mu \mathrm{g}$ STX eq $\cdot 100^{-1}$.

\section{MATERIALS AND METHODS}

Study areas and sampling design. Preliminary study-area selection was based on historic patterns of butter clam toxicity (Alaska Department of Environmental Conservation bivalve time series data, Kvitek et al. 1991) and recent sea otter range expansion information (Agler et al. 1995, J. Botkin pers. comm.). Because prey toxicity results for this project were received from the Alaska Department of Environmental Conservation following the completion of each season's fieldwork, all sampling site selection and data collection was conducted without prior knowledge of the current concentrations of prey toxicity. Specific sampling sites were selected at locations where observers found sea otters to be actively feeding during the small-boat surveys (see below). Thirteen general study areas, each with one or more specific sampling sites (46 total), were selected (Fig. 1). Foraging observations could only be conducted at 16 of these sampling sites, those where sea otters were most numerous, due to the limited amount of field time available. Prey and shell record data, however, were collected at nearly all sites.

The NSF-UNOLS ship, RV 'Alpha Helix', provided the research platform from which we launched small boats for sea otter feeding observations and SCUBA sampling. Research cruises of 22 and $17 \mathrm{~d}$ took place during the summer of 1998 and 1999, respectively. Within each study area we sought to assess and quantify sea otter diet and foraging behavior, as well as prey availability, composition, abundance, and PSPT toxicity. Methods included direct observation of feeding sea otters, SCUBA diver sampling of prey shells and tissues discarded by feeding otters, as well as live prey abundance. Data from both sampling years were pooled for statistical purposes, and all percent data were log transformed prior to analyses. Statistical analyses (ANOVA and $t$-test) were per- formed using Statview for Windows v 5.0. All transformed data were evaluated for and met assumptions for the parametric tests.

Sea otter distribution. Prior to selecting specific sampling sites, each general study area was subdivided and thoroughly surveyed via small boat ( 3 to 4 boats with 3 observers per boat) to locate sites with feeding sea otters. A total of $15 \mathrm{~d}$ were spent on boat surveys. In addition to sampling site selection, the boat survey results were used to determine the extent of sea otter range expansion beyond the limits identified during our previous sea otter prey studies completed in 1990 (Kvitek \& Oliver 1992, Kvitek et al. 1993) (Fig. 1). Waterproofed nautical charts and Global Positioning units (GPS) were provided to all survey teams for accurate survey navigation and data logging. When sea otters were encountered, the number of individuals in the group, including number of pups, and their general activity (feeding, resting, etc.) were recorded on the survey chart, and a corresponding GPS position was noted.

Toxicity analyses. Tissues from the dominant bivalve prey species were collected by divers and retained from each site for later PSPT analyses. Depending on availability, tissues were pooled for each species at each site to make up the requisite $100 \mathrm{~g}$ samples for analysis. PSPT analysis was not performed for those species too rare to yield $100 \mathrm{~g}$ of tissue at a given site. This approach provided average prey toxicity values for each tested species at each site. At sites where sea otters were observed to discard butter clam tissues, an additional butter clam collection was made to allow separate testing of siphons (the most toxic part of the butter clam; Beitler \& Liston 1990) and bodies without siphons. The actual tissues discarded by feeding sea otters were also collected along $1 \times 10 \mathrm{~m}$ quantitative transect lines and analyzed separately.

Standard protocols for handling and shipping samples were followed for transporting prey tissues to the Alaska Department of Environmental Conservation in Palmer, Alaska, where the PSPT mouse bioassays were performed. Bioassay results were reported in $\mu \mathrm{g}$ STX equivalent (eq.) per $100 \mathrm{~g}$ of tissue (Laycock et al. 1994). For statistical comparisons, toxicity data were binned by range according to threshold values associated with patterns in sea otter foraging behavior observed in the field.

Sea otter diet and foraging behavior. Sea otter diet composition, foraging behavior (including dive times, surface intervals, feeding rate and foraging success), and prey tissue rejection were determined at selected feeding sites via direct observation (after Kvitek et al. 1991, 1993). Within each chosen feeding area, typically 3 shore observation sites, each with 3-person crews (observer, recorder and relief), were established to fol- 
low individual feeding otters. Occasionally, observations were conducted from the small survey boats. A total of $22 \mathrm{~d}$ were devoted to feeding observations. Observers used spotting telescopes $(60 \times)$ and binoculars. The active observer of each crew selected a single feeding sea otter as a 'focal' animal, identified its sex (presence or absence of penile bulge), recorded the presence of pups, and noted the beginning and ending time of each dive. Whenever possible the focal otter was followed for $30 \mathrm{~min}$, or until it stopped feeding, or moved out of range.

If the focal sea otter brought a prey item to the surface, the dive was considered successful and the observer identified the number and type of prey to the lowest taxonomic category possible. Butter clams can generally be recognized during feeding observations due to their characteristic size, shape and color (Kvitek et al. 1993). Additionally, observers were provided with laminated photo field guides of local benthic species to aid in prey identification. Taxonomic classification of prey species was also independently determined via diver collection of shells discarded by the feeding otters (see next section).

Prey size was estimated relative to otter paw size $(\approx 5 \mathrm{~cm})$ (after Kvitek et al. 1993). Although coarse, this technique provided a reliable method of grouping sea otter prey into relative categories of $5 \mathrm{~cm}$ size intervals, thus aiding in the discrimination of different prey species. The observer also noted whether or not the feeding otter discarded uneaten tissue, particularly the large siphon of butter clams, as observed in prior captive feeding experiments (Kvitek et al. 1991). A $t$-test was used to test for a significant difference between percent butter clam tissue rejections at different levels of tissue toxicity at each site where prey was discarded. In addition to following the focal sea otter, the observation crew continually scanned the surrounding area for other feeding sea otters, and kept a record of their prey items as well.

Determination of sea otter diet from shell records. Divers collected all bivalve shells recently discarded by sea otters from within $1 \mathrm{~m}^{2}$ quadrats randomly placed on the sea floor at each study site. A minimum of 100 otter-opened shells was collected at each study site. Shells from sea-otter-eaten bivalves are easily distinguished from those which have been subject to other causes of death and predation (Ambrose et al. 1988, Kvitek et al. 1992). The shells were sorted by species, measured to the nearest $\mathrm{mm}$, and categorized as 'recent' or 'old' mortality type. Divers also collected any tissues found within their quadrats, particularly butter clam siphons that appeared to have been rejected by feeding otters. These discarded tissue samples were frozen for separate PSPT analyses. ANOVA was used for statistical comparisons of prey toxicity versus per- cent otter-cracked butter clams in the shell record and percent butter clams in the otter-cracked shell record.

Available prey. Divers sampled available live prey using in situ benthic transects and quadrats for shipboard analysis of species composition, size, abundance and biomass. Data for calculating density, biomass and sizes of infaunal bivalves $\geq 30 \mathrm{~mm}$ was obtained at sea otter feeding sites by excavating bivalves from randomly placed $0.25 \mathrm{~m}^{2}$ quadrats to a depth of $50 \mathrm{~cm}$ by hand-digging and a SCUBA diver-operated dredge (after Kvitek \& Oliver 1992, Kvitek et al. 1992). Samples were transported to the ship's laboratory where bivalves were identified, shell lengths measured to the nearest $\mathrm{mm}$, and biomass calculated from these lengths based on previously established length-toweight ratios for each species (Kvitek et al. 1991, Kvitek \& Oliver 1992). Size, abundance, and biomass versus binned toxicity data (see below) were independently compared using ANOVA.

In addition to infaunal bivalve prey, sea otters often target sea urchins at recently occupied sites (Kvitek \& Oliver 1992). Because sea urchins are not known to accumulate PSPT, they also present a likely alternative prey to those species that do. As a result, red (Strongylocentrotus franciscanus) and green (S. droebachiensis) urchin abundance and size were sampled the depth of their greatest abundance at each site. Divers used randomly placed quadrats $\left(0.25 \mathrm{~m}^{2}\right)$ and transects $(1 \times 10 \mathrm{~m})$ to determine urchin abundance. Rocks $\leq 1 \mathrm{~m}^{2}$ encountered along transects were turned over and inspected for sea urchins. Divers collected and then measured the test diameter of all urchins encountered in randomly placed quadrats $\left(0.25 \mathrm{~m}^{2}\right)$ to obtain mean size for both species. Collected urchins were also weighed to determine biomass values.

Benthic megafauna (e.g. anemones, sea cucumbers, crabs, sea stars, etc.) densities were recorded along larger 2 or $3 \times 25 \mathrm{~m}$ transect lines. Abundance of deepburrowing geoduck bivalves Panopea abrupta was estimated by counting siphons protruding from the sediment within $0.25 \mathrm{~m}^{2}$ quadrats, and $P$. abrupta size distribution was estimated from recent shell record remains.

\section{RESULTS}

\section{Sea otter distribution}

The small boat surveys revealed that the sea otter range in southeast Alaska had indeed expanded in several areas since our previous survey of their range completed in 1990 (Fig. 1). Sea otters were found foraging in Glacier Bay and Icy Passage to the north, in the vicinity of Sitka along the outer coast of Baranof 
Island, extending up the east side of Chatham Strait to the north end of Kuiu Island, throughout Sea Otter Sound and along the east side of Sumner Strait to the north end of Prince of Wales Island, and south of Noyes Island to Cape Chirikof on Baker Island. Sea otter distribution and abundance were summarized for statistical comparison with prey toxicity by calculating the number of sea otters found during the boat surveys that were within $3 \mathrm{~km}$ of each selected feeding observation and prey sampling site (Fig. 2a). Three $\mathrm{km}$ was chosen as reasonable bin size for the number of sea otters likely to be foraging on prey of similar toxin concentrations (Jameson 1989, Riedman \& Estes 1990).

\section{Toxicity analyses}

Bivalve PSPT toxicity values were obtained from 106 bivalve tissue samples collected at 42 sites in 12 general areas. Tissue PSPT concentrations above the level expected to affect sea otter foraging behavior $(148 \mu \mathrm{g}$ STX eq $\cdot 100 \mathrm{~g}^{-1}$, Kvitek et al. 1991) were found in bivalve prey at all sites within 2 general areas where foraging sea otters were abundant, Icy Passage to the north, and Sea Otter Sound to the south (Fig. 1). Toxin concentrations are summarized for each species across all feeding sites within each of these general areas in Table 1. In the Icy Passage area, the majority of all tested bivalve species had toxin concentrations above $1000 \mu \mathrm{g} \mathrm{STX} \mathrm{eq} \cdot 100 \mathrm{~g}^{-1}$ and all were nearly twice the predicted sea otter behavioral change threshold range

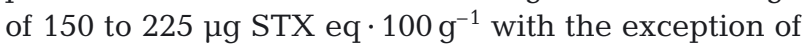
Macoma spp., which was at the extreme lower end of this range $\left(157 \mathrm{\mu g}\right.$ STX eq $\left.\cdot 100 \mathrm{~g}^{-1}\right)$. The high PSPT values for the non-butter clam species known to depurate these toxins quickly (Shumway 1990) indicate that a toxic bloom was in progress or had recently ended.

At Sea Otter Sound, however, butter clams and Gari californica were the only bivalve species within or higher than the predicted change-inducing PSPT range of 150 to $225 \mu \mathrm{g} \mathrm{STX} \mathrm{eq} \cdot 100 \mathrm{~g}^{-1}$, with most other species near the detection limit of the mouse bioassay method, suggesting that some weeks or months had passed since the last major toxic bloom event (Table 1). It was also in the Sea Otter Sound feeding area that otters were observed discarding tissues from butter clams (see next section). These discarded tissues, primarily siphons, when pooled and analyzed were found to contain $543 \mu \mathrm{g}$ STX eq $\cdot 100 \mathrm{~g}^{-1}$. Separate toxicity analysis results for pooled siphons (946 $\mu \mathrm{g}$ STX eq $\left.\cdot 100 \mathrm{~g}^{-1}\right)$ and bodies without siphons (340 $\mathrm{\mu g}$ STX eq $\cdot 100 \mathrm{~g}^{-1}$ ) from the butter clams excavated by divers $(\mathrm{n}=11)$ at this same discard site were consistent with the sea otters' siphon discard strategy for reducing prey toxicity, but also indicated that sea otters were
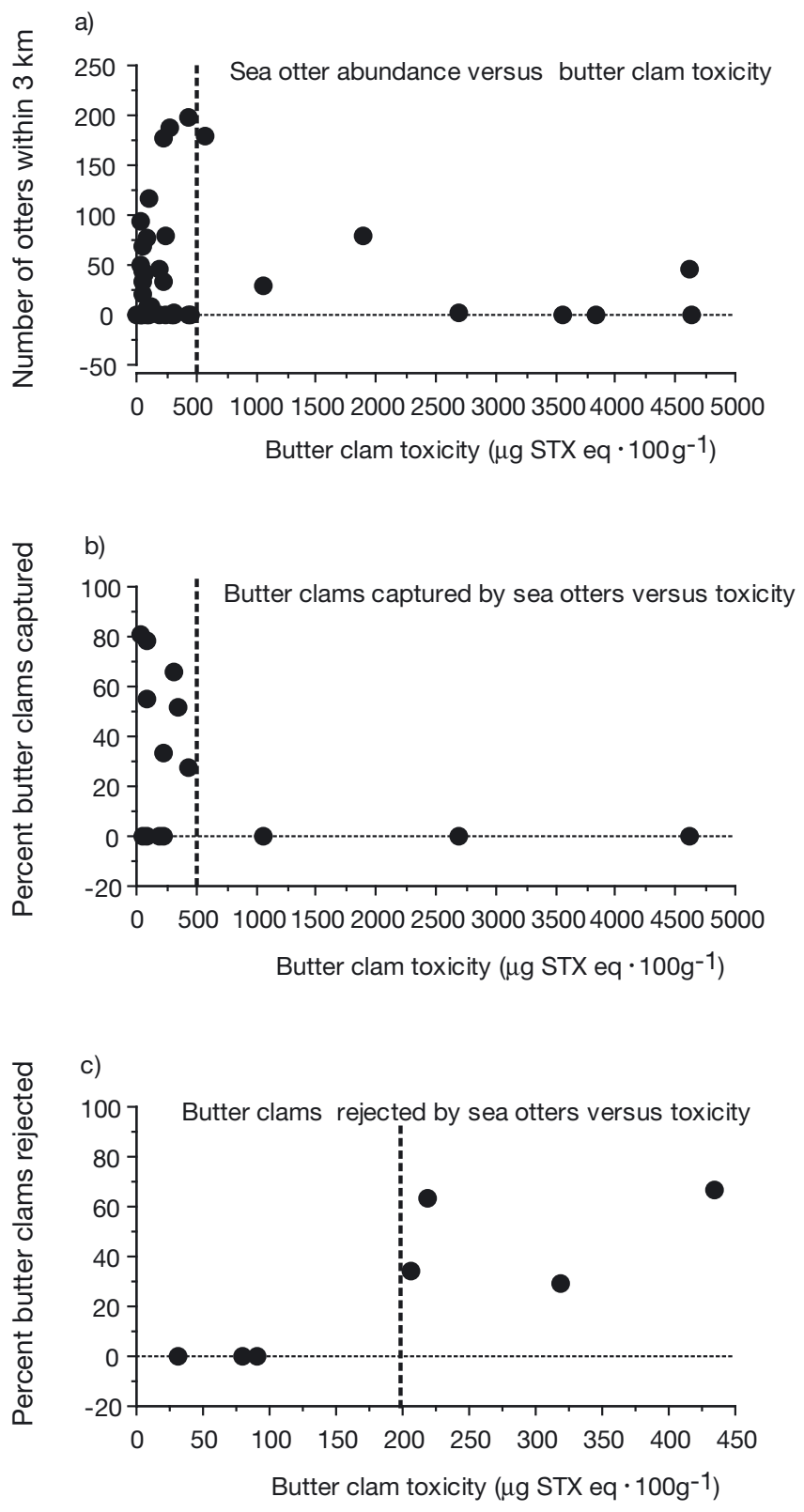

Fig. 2. Enhydra lutris and Saxidomus giganteus. Scatter plots of data from individual sea otter feeding sites showing the relationship between butter clam toxicity and (a) number of sea otters found within $3 \mathrm{~km}$ of prey sampling site, (b) percentage of observed prey captured by feeding sea otters identified as butter clams, and (c) percentage of observed butter clam capture events in which sea otters discarded all or a portion of the captured individual. Vertical lines represent threshold concentrations of prey toxicity at which sea otter foraging behavior changed

able to forage on clams containing considerably higher concentrations of PSPT than originally predicted. The density of these discarded siphons was $2.5 \pm 2.8 \mathrm{~m}^{-2}$ ( $\mathrm{n}=100$ individuals from four $1 \times 10 \mathrm{~m}$ transects). 
Table 1. Prey toxicity (mean $\mu \mathrm{g}$ STX eq $\cdot 100 \mathrm{~g}^{-1}$ for bivalve prey species), population status (mean abundance, size [shell length] and biomass [wet meat weight],$\pm \mathrm{SD}$ ) and frequency of occurrence in sea otter diet Enhydra lutris (otter-cracked shell record and observed prey captures) within the 2 most toxic general sea otter foraging areas (Icy Passage and Sea Otter Sound). nd = below detection limit of mouse bioassay. STX: saxitoxin

\begin{tabular}{|c|c|c|c|c|c|c|}
\hline Species & $\begin{array}{c}\text { Toxicity } \\
\text { Ig STX eq } \cdot 100 \mathrm{~g}^{-1} \text { ) }\end{array}$ & $\begin{array}{l}\text { Abundance } \\
\text { (ind. } 0.25 \mathrm{~m}^{-2} \text { ) }\end{array}$ & $\begin{array}{l}\text { Size } \\
(\mathrm{mm})\end{array}$ & $\begin{array}{c}\text { Biomass } \\
\left(\mathrm{g} 0.25 \mathrm{~m}^{-2}\right)\end{array}$ & $\begin{array}{c}\text { Frequency in } \\
\text { shell record (\%) }\end{array}$ & $\begin{array}{l}\text { Frequency in } \\
\text { captures (\%) }\end{array}$ \\
\hline \multicolumn{7}{|l|}{ Icy Passage } \\
\hline Clinocardium spp. & 1059 & $0.1 \pm 0.4$ & $58 \pm 30$ & $2 \pm 14.2$ & 1 & $<1$ \\
\hline Humilaria kennerleyi & 1017 & $0.5 \pm 1.7$ & $80 \pm 5$ & $14 \pm 49$ & 0 & 0 \\
\hline Macoma spp. & 157 & $0.2 \pm 0.5$ & $40 \pm 18$ & $1 \pm 4$ & 61 & 21 \\
\hline Mya truncata & 1461 & $1.1 \pm 3.0$ & $51 \pm 9$ & $16 \pm 45$ & 0 & 0 \\
\hline Pecten caurinus & 362 & $0.3 \pm 0.6$ & 220 & $120 \pm 240$ & 0 & 0 \\
\hline Protothaca staminea & 346 & $2.5 \pm 4.7$ & $48 \pm 6$ & $19 \pm 36$ & 4 & 0 \\
\hline Saxidomus giganteus & 2166 & $15.8 \pm 16.1$ & $74 \pm 14$ & $637 \pm 615$ & 15 & 0 \\
\hline Mactromeris polynyma & 1582 & $0.4 \pm 0.9$ & $92 \pm 26$ & $37 \pm 93$ & 18 & 1 \\
\hline Tresus capax & 1429 & $0.2 \pm 0.6$ & $126 \pm 54$ & $36 \pm 136$ & 0 & 0 \\
\hline Sea urchin & & $21.4 \pm 16.0$ & $58 \pm 11$ & $5 \pm 2$ & & 44 \\
\hline Sea pen & & $2.4 \pm 2.0^{\mathrm{a}}$ & & & & 2 \\
\hline Crab & & $1.6 \pm 0.8^{\mathrm{a}}$ & & & & 8 \\
\hline Unidentified & & & & & & 23 \\
\hline \multicolumn{7}{|l|}{ Sea Otter Sound } \\
\hline Gari californica & $177 \pm 75$ & $0.8 \pm 1.3$ & $62 \pm 11$ & $14 \pm 23$ & 17 & 0 \\
\hline Panopea abrupta & nd & $4.0 \pm 3.9$ & $141 \pm 14$ & $3152 \pm 3073$ & 6 & 2 \\
\hline Humilaria kennerleyi & $44 \pm 16$ & $1.6 \pm 2.4$ & $66 \pm 14$ & $39 \pm 73$ & 8 & 1 \\
\hline Mya truncata & $22 \pm 19$ & $0.2 \pm 0.8$ & $53 \pm 6$ & $4 \pm 15$ & 6 & 1 \\
\hline Protothaca staminea & $18 \pm 17$ & $3.2 \pm 6.8$ & $50 \pm 12$ & $24 \pm 40$ & 9 & 0 \\
\hline Saxidomus giganteus & $358 \pm 149$ & $6.3 \pm 12.8$ & $71 \pm 20$ & $248 \pm 462$ & 51 & 10 \\
\hline Unidentified clam & & & & & & 52 \\
\hline Sea urchin & & 0 & & & & 1 \\
\hline Unidentified & & & & & & 24 \\
\hline${ }^{\mathrm{a}} 2 \times 25 \mathrm{~m}$ transect & & & & & & \\
\hline
\end{tabular}

No significant relationship was found between sea otter distribution and butter clam toxicity, even when stratifying that analysis by the $500 \mu \mathrm{g}$ STX eq $\cdot 100 \mathrm{~g}^{-1}$ concentration at which sea otters apparently stop foraging on butter clams (see next section) (Fig. 2a) $(t$-test, $\mathrm{df}=38, t=0.070, \mathrm{p}=0.94)$.

\section{Sea otter diet and foraging behavior}

Foraging observations were conducted at 16 of the 33 identified sea otter feeding sites in 6 of the 13 preselected general areas, involving 242 individual focal otters making 3450 foraging dives. These observations documented 2344 individual prey items, the majority of which were bivalves $(56 \%)$, followed by unidentified $(25 \%)$, sea urchins $(10 \%)$, crabs $(7 \%)$, gumboot chitons Chryptochiton stelleri (1\%), sea stars $(1 \%)$, sea pens Ptilosarcus gurneyi $(<1 \%)$ and octopus $(<1 \%)$. Butter clams made up the majority of the bivalve prey items that could be identified to species during feeding observations, and because they were the most widespread, easily identified, persis- tently toxic and frequently captured prey items by sea otters, our diet and foraging behavior analyses, as well as hypothesis testing, are focused on this species.

When sea otter feeding behavior was examined in relationship to toxicity values of available prey at each feeding site, 2 patterns emerged. At 'highly toxic' sites where all sampled bivalve prey toxicities, with the exception of those for Macoma spp., were $>500 \mu \mathrm{g}$ STX eq $\cdot 100 \mathrm{~g}^{-1}$, sea otters were rarely $(\leq 1 \%)$ observed capturing any of these highly toxic, larger bivalve species (Icy Passage feeding areas, Table 1). Instead, the sea otters foraged primarily on small green sea urchins (44\%), small Macoma spp. clams (21\%), crab (9\%), sea pens $(2 \%)$ and unidentified prey $(23 \%)$. This pattern of highly toxic prey avoidance is clearly seen in Fig. 2b, where significantly fewer butter clams $(0 \%)$ were observed being captured by sea otters at sites where butter clam toxicity was $>500 \mu \mathrm{g}$ STX eq $\cdot 100 \mathrm{~g}^{-1}$ versus $<500 \mu \mathrm{g} \mathrm{STX} \mathrm{eq} \cdot 100 \mathrm{~g}^{-1}(t$-test, $\mathrm{df}=12, t=$ $-1.974, \mathrm{p}=0.036$ ).

The second sea otter foraging pattern related to prey toxicity was observed at feeding sites of 'intermediate 
toxicity', where butter clam toxin concentrations were between 200 and $500 \mu \mathrm{g}$ STX eq $\cdot 100 \mathrm{~g}^{-1}$ and other potential bivalve prey species were below $200 \mu \mathrm{g}$ STX eq $\cdot 100 \mathrm{~g}^{-1}$ (Sea Otter Sound feeding areas, Table 1). It was at these sites, and only these sites, that sea otters were observed rejecting or discarding any captured prey, and it was only butter clams that were rejected (Fig. 2c). Statistically, there was a significantly higher frequency of sea otters discarding butter clams at sites where this species' toxicity was $>200 \mu \mathrm{g}$ STX eq $\cdot 100 \mathrm{~g}^{-1}$ ( $t$-test, df $\left.=5, t=6.49, \mathrm{p}=0.001\right)$, but sea otters were never observed even capturing butter clams in areas where their toxicity was >500 $\mu \mathrm{g}$ STX eq $\cdot 100 \mathrm{~g}^{-1}$. These findings suggest that 200 and $500 \mu \mathrm{g}$ STX eq $\cdot 100 \mathrm{~g}^{-1}$ are the threshold concentrations for changes in sea otter foraging behavior, and as a result these 2 toxin concentrations where used to group the feeding and sampling sites for the statistical analyses presented here.

\section{Determination of diet from shell records}

Divers collected over 7600 shells at 43 sea otter feeding sites in 13 general areas. Shells of recent origin were used to characterize sea otter diet composition and to quantify the relative proportions of different sources of bivalve mortality (sea otter, crab, moon snail, octopus, sea star). These shell record analyses confirmed that sea otters change their feeding habits when bivalve prey PSPT concentrations exceed 500 $\mu \mathrm{g}$ STX eq. $100 \mathrm{~g}^{-1}$ (Fig. 3). Otter predated butter clam shells made up a significantly smaller proportion of all otter-cracked shells collected at feeding sites where butter clam toxicity was $>500 \mu \mathrm{g}$ STX eq $\cdot 100 \mathrm{~g}^{-1}(28 \%)$ versus $<500 \mu \mathrm{g}$ STX eq $\cdot 100 \mathrm{~g}^{-1}$ $(57 \%)(t$-test, df $=36, t=2.28, \mathrm{p}=0.028)$ (Fig. 3a). Indeed, in this highly toxic area, Macoma spp., the only bivalve found to be below 200 or $500 \mu \mathrm{g}$ STX eq $\cdot 100 \mathrm{~g}^{-1}$, made up $61 \%$ of all the recent otter-predated shells collected, whereas none of the highly toxic species accounted for more than 18\% (Table 1). Conversely, at the Sea Otter Sound feeding sites, where butter clams were $>200$ but $<500 \mu \mathrm{g}$ STX eq $\cdot$ $100 \mathrm{~g}^{-1}$, and all other bivalves were well below 200 $\mu \mathrm{g}$ STX eq. $100 \mathrm{~g}^{-1}$, butter clams accounted for the majority of the shells in the recent otter-cracked record (Table 1).

When considering only the butter clam shell record from all sources of predation, sea otter predation accounted for a significantly smaller proportion of butter clam mortality at the sites where this species toxicity was $>500 \mu \mathrm{g} \mathrm{STX} \mathrm{eq} \cdot 100 \mathrm{~g}^{-1}(14 \%)$ versus $<500 \mu \mathrm{g}$ $\mathrm{STX} \mathrm{eq} \cdot 100 \mathrm{~g}^{-1}(38 \%)$ ( $t$-test, $\mathrm{df}=41, t=2.47, \mathrm{p}=$ 0.018) (Fig. 3b).
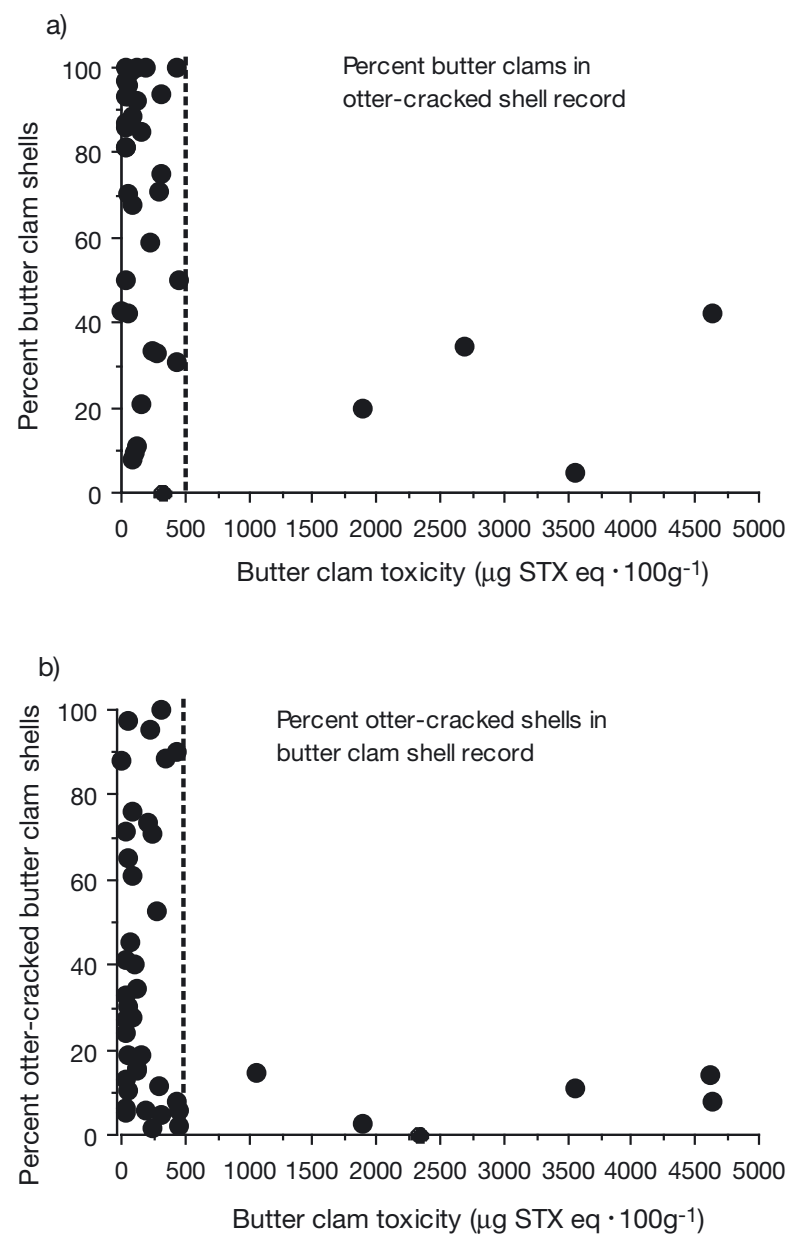

Fig. 3. Enhydra lutris and Saxidomus giganteus. Scatter plots of shell-record data from individual sea otter feeding sites showing the relationship between butter clam toxicity and (a) the percentage of butter clam shells found among all collected bivalve shells that had been opened by sea otters, and (b) the percentage of otter-cracked shells among all recently predated butter clam shells from all sources of mortality collected at each site

\section{Available prey}

Bivalve prey abundance, size and biomass were quantified from 4861 individuals collected in 258 excavations of $0.25 \mathrm{~m}^{2}$, dug by divers at 32 sites (6 excavations per site) in 12 general areas. Prey abundance, size and biomass are summarized in Table 1 for the 2 most important sea otter feeding areas associated with toxic prey, Icy Passage and Sea Otter Sound. These were the 2 toxic prey areas in which the greatest observational and sampling effort was expended, thereby giving the most complete picture of how sea otters respond to elevated concentrations of PSPT in their prey.

Butter clams were selected as the best overall indicator of the relationship between sea otter prey availabil- 
Table 2. Saxidomus giganteus. Abundance (ind. $\left.\cdot 0.25 \mathrm{~m}^{-2}\right)$, size $(\mathrm{mm})$ and biomass $\left(\mathrm{g} \cdot 0.25 \mathrm{~m}^{-2}\right.$ ) were all significantly lower (one 1-tailed $t$-test) at sea otter occupied sites where $S$. giganteus paralytic shellfish poisoning (PSP) toxicity levels were low ( $<500 \mathrm{mg}$ STX eq $\cdot 100 \mathrm{~g}^{-1}$ tissue weight) than at otter sites where $S$. giganteus PSP toxicity levels were high $\left(>500 \mathrm{mg}\right.$ STX eq $\cdot 100 \mathrm{~g}^{-1}$ tissue weight). Data are means $\pm \mathrm{SD} ; \mathrm{N}=$ number of sites

\begin{tabular}{|lcccc|}
\hline & Abundance & Size & Biomass & N \\
\hline Low toxicity & $6.8 \pm 7.7$ & $60.4 \pm 17.6$ & $215 \pm 330$ & $21-22$ \\
High toxicity & $16.5 \pm 17.5$ & $74.6 \pm 10.2$ & $541 \pm 481$ & 5 \\
$\mathrm{p}$ & 0.0261 & 0.0492 & 0.0403 & \\
\hline
\end{tabular}

$100 \mathrm{~g}^{-1}$. At these highly toxic sites, foraging sea otters were never observed to capture butter clam prey (Fig. 2b), despite the high abundance of this species at these sites (Table 2). Instead, otters were observed to forage on small and rare Macoma spp. clams, sea pens, and sea urchins, while avoiding 7 other highly toxic bivalve species that were much larger and more abundant (Table 1). This prey-avoidance behavior is very unusual for sea otters, a spe-

ity and status versus toxicity for 2 reasons. This species had the widest and most continuous range of PSPT toxicity values (non-detect to $>4500 \mu \mathrm{g}$ STX eq $\cdot 100 \mathrm{~g}^{-1}$ ) found throughout the study areas, and, unlike all other prey species sampled, butter clams were found in every study area. Butter clam abundance, size and biomass were all significantly lower at sea otter sites where butter clam toxicity was $<500 \mu \mathrm{g}$ STX eq $\cdot 100 \mathrm{~g}^{-1}$ than at sea otter sites where butter clam toxicity was $>500 \mu \mathrm{g}$ STX eq $\cdot 100 \mathrm{~g}^{-1}(t$-tests, $\mathrm{df}=$ $25, \mathrm{p}=0.049,0.026$, and 0.033 respectively) (Table 2 ).

When butter clam size data from otter and non-otter occupied sites were combined, both toxicity and sea otter presence were found to have a significant effect on size distribution (ANOVA p $=0.042$ and 0.009 respectively). Butter clams were larger at non-otter versus otter sites where butter clam toxicity was $<500 \mu \mathrm{g}$ STX eq $\cdot 100 \mathrm{~g}^{-1}$, but not at sites where this species' toxicity was $>500 \mu \mathrm{g}$ STX eq $\cdot 100 \mathrm{~g}^{-1}$.

\section{DISCUSSION}

\section{Site avoidance hypothesis not supported}

No evidence was found in support of site avoidance by sea otters due to HAB-related prey toxicity. Sea otters were found at many sites where the toxicity of butter clams (Fig. 2a), as well as all other large bivalve prey (Table 1), exceeded $225 \mu \mathrm{g}$ STX eq $\cdot 100 \mathrm{~g}^{-1}$ by a wide margin. Indeed, sea otters were found foraging in areas where butter clams and other high-value bivalve prey species contained the highest PSPT concentrations recorded during this study (1000 to $>4500 \mu \mathrm{g}$ STX eq $\cdot 100 \mathrm{~g}^{-1}$ ) (Table 1, Fig. 2).

\section{Prey switching and testing at highly toxic sites $\left(>500 \mu \mathrm{g} \mathrm{STX} \mathrm{eq} \cdot 100 \mathrm{~g}^{-1}\right.$ )}

There was strong evidence for prey switching at sites where the toxicity of the preferred butter clam prey exceeds a threshold concentration of $500 \mu \mathrm{g}$ STX eq cies with a well-documented preference for butter clams and other large energy-rich prey in disproportion to their relative abundance (Ostfeld 1982, Kvitek \& Oliver 1992).

Although sea otters were never observed to capture butter clams at the highly toxic sites (>500 $\mu \mathrm{g}$ STX eq $100 \mathrm{~g}^{-1}$ ) (Fig. 2b), the presence of a very few butter clam shells in the recent otter-cracked shell record at these sites (Fig. 3a) indicates that sea otters continue to capture, open and test a small number of butter clam prey above this threshold toxicity concentration. Shell record and foraging observation evidence also show that sea otters had been occasionally testing the large, abundant, and highly toxic bivalve Mactromeris polynyma (Alaskan surf clam) in the Icy Passage area, but that this species was only rarely taken as prey (Table 1). Of interest is the fact that $M$. polynyma is closely related to another Mactrid clam, the Atlantic surf clam Spisula solidissima, known to accumulate and retain PSPT at high concentrations for months or years (Shumway et al. 1994).

\section{Prey rejection at sites of intermediate prey toxicity $\left(200\right.$ to $\left.500 \mu \mathrm{g} \mathrm{STX} \mathrm{eq} \cdot 100 \mathrm{~g}^{-1}\right)$}

Sea otters were observed to discard butter clam tissues only at sites where whole butter clam toxicity values were between 200 and $500 \mu \mathrm{g} \mathrm{STX} \mathrm{eq \cdot} 100 \mathrm{~g}^{-1}$ (Fig. 2c). It was also only at these sites that dense patches of discarded and highly toxic butter clam siphon tissues were found. As demonstrated in prior captive-feeding results (Kvitek et al. 1991), sea otters modified their feeding behavior so as to reduce the overall toxicity of ingested butter clam prey by discarding those tissues containing the majority of sequestered toxins. Interestingly, at these same prey-discard sites, female sea otters were observed dismantling butter clams, discarding tissue, and then offering small pieces of the remaining body tissue to the pups. Sea otters were never observed discarding tissues of any other captured prey species, nor from butter clams at any sites where the prey toxicity was below $200 \mu \mathrm{g}$ STX eq $\cdot 100 \mathrm{~g}^{-1}$. 


\section{Sequestered PSPT as a refuge from sea otter predation}

Three lines of evidence support the hypothesis that sea otters generally avoid butter clam prey at sites where this species is abundant but contains $>500 \mu \mathrm{g}$ STX eq $\cdot 100 \mathrm{~g}^{-1}$ (Table 2). The relative frequency of butter clams observed captured by feeding sea otters (Fig. 2b), and butter clam shells present in the ottercracked shell record, were both significantly lower at sites where butter clam toxicity was $>500 \mu \mathrm{g}$ STX eq $100 \mathrm{~g}^{-1}$. Also, the percentage of otter-cracked shells within the total recent butter-clam shell record was significantly lower at these same highly toxic sites, indicating that sea otters were responsible for a smaller fraction of this species' overall mortality rate at high versus low toxicity sites (Fig. 3b).

It was not surprising, therefore, to find butter clam size, abundance and biomass were all significantly greater at highly toxic sea otter feeding sites where butter clams contained $>500 \mu \mathrm{g}$ STX eq $\cdot 100 \mathrm{~g}^{-1}$ than at sites where butter clam toxicities were below this value (Table 2). This pattern is consistent with previous reports of bivalve population status in areas of higher and lower levels of sea otter predation (Kvitek \& Oliver 1992, Kvitek et al. 1992), as well as the results from this study at sites with and without sea otters.

\section{CONCLUSIONS}

Taken as a whole, these results reveal 2 threshold concentrations within a graded behavioral response to bivalve prey toxicity on the part of foraging sea otters that effectively limit this predator's exposure to potentially lethal HAB toxins. Sea otters foraged normally on all bivalve prey up to a PSPT concentration of approximately $200 \mu \mathrm{g} \mathrm{STX} \mathrm{eq} \cdot 100 \mathrm{~g}^{-1}$. Above this concentration, sea otters adapted their feeding behavior to exploit the anatomical distribution of PSPT sequestered in their preferred butter clam prey. By discarding the more highly toxic siphon, sea otters were able to feed on butter clams with whole body toxicities

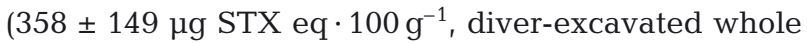
clams) above the concentration that generally stimulates avoidance. These same types of prey testing and selective discarding behaviors for avoiding or circumventing toxic defenses are seen in avian predators of chemically defended insects (Brower \& Glazier 1975, Calvert et al. 1979, Fink \& Brower 1981, Brower 1984, Brower \& Calvert 1985, Brower \& Fink 1985).

The second shift in foraging behavior occurred at $500 \mu \mathrm{g}$ STX eq $\cdot 100 \mathrm{~g}^{-1}$. At this concentration, sea otters stop foraging on butter clams and shift to alternate and less toxic prey. Even at these higher toxin concentrations, however, the shell record data indicate that sea otters continue to occasionally capture and test these toxic but otherwise preferred prey species. Nevertheless, the ability of butter clams to sequester and retain PSPT from one HAB season to the next confers a refuge from sea otter predation, as evidenced by the significantly higher abundance, size and biomass of butter clams at sea otter foraging sites where butter clam PSPT concentrations exceed $500 \quad \mu g$ STX eq $\cdot 100 \mathrm{~g}^{-1}$. Thus, while the ability to sequester STX and its analogues may not have evolved in response to sea otter predation (Brower et al. 1988, Kvitek \& Beitler 1991), it nonetheless functions as a chemical defense, altering the prey preference of this keystone predator, and thereby the structure of its benthic prey assemblage. Persistence of the refuge, however, will likely depend on the continued annual recurrence of seasonal HAB events, as sea otters remain and monitor bivalve PSPT concentrations in these areas.

Although these results suggest that some high-level marine predators are able to detect and avoid ingestion of lethal concentrations of HAB toxins, this ability may only apply to cases in which the predator's feeding behavior, combined with the anatomical distribution of these toxins in the prey, enable the predator to 'test' the prey prior to ingestion. Sea otters open or chew bivalve prey, exposing all the soft organ tissues to contact with the inside of their mouth prior to swallowing. Thus, if sea otters are able to 'taste' or otherwise detect the presence of HAB toxins, they have the opportunity of rejecting these opened prey before swallowing them. The ability to test prey for HAB toxins is likely not the case for piscivorous species such as pinnipeds, whales and sea birds, the marine predators most commonly associated with HAB-related mass mortalities (Keyes 1965, Nisbet 1983, Work et al. 1993, Berta \& Sumich 1999, Lefebvre et al. 1999, Scholin et al. 2000, Lefebvre et al. 2001). These species typically swallow their small fish prey whole, often during feeding frenzies, such that HAB toxins contained in the stomachs of their prey would not be released into the predator's system until digestion takes place, well after the feeding event. Under these circumstances, it is less likely that HAB toxins would alter feeding behavior or provide a deterrent to predation.

Acknowledgements. We thank the following researchers for assistance with foraging observations and SCUBA sampling: K. Thomas, P. Iampietro, E. Sandoval, K. Conlan, B. Head, S. Lamerdin, K. Carlson, E. Ross, M. Castleton, S. Maldonado, L. Dippold, M. Silberstein, M. Patyten, N. Slattery, M. Ferdin, T. Manouki, S. Kvitek, L. Lunsten, and P. Mullins. Special thanks to the dedicated crew of RV 'Alpha Helix' for their generous logistical support during this project. Also thanks to D. Barrett and C. Allison of the Alaska Department of Environmental Conservation, Palmer, Alaska, for their timely 
tissue analyses for PSPT, and S. Alexander, J. Barry, G. Doucette, J. Estes, H. Kibak, C. Scholin, M. Silver, and S. Worcester for their pre-submission reviews. This project was funded through NSF/ECOHAB Grant\# OCE-9726263 to R.G.K.

\section{LITERATURE CITED}

Agler BA, Kendall SJ, Seiser PE, Lilndell JR (1995) Estimates of birds and sea otter abundance in southeast Alaska during summer 1994. US Fish and Wildlife Report, Fairbanks, AK

Ambrose RF, Leighton BJ, Hartwick EB (1988) Characterization of boreholes by Octopus dofleini in the bivalve Saxidomus giganteus. J Zool 214:491-503

Anderson DM (1997) Turning back the harmful red tide. Nature 388:513-514

Anderson DM, Kaoru Y, White AW (eds) (2000) Estimated annual economic impacts from harmful algal blooms (HABs) in the United States. Woods Hole Oceanographic Institution, Technical Report WHOI-2000-11, Woods Hole

Armstrong IH, Coulson JC, Hawkey P, Hudson MJ (1978) Further mass seabird deaths from paralytic shellfish poisoning. Br Birds 71:58-68

Bates SS (1997) Toxic phytoplankton on the Canadian east coast: implications for aquaculture. Bull Aquac Assoc Can 97:9-18

Beitler MK, Liston J (1990) Uptake and tissue distribution of PSP toxins in butter clams. In: Graneli JR, Sundström EB, Edler L, Anderson DM (eds) Toxic marine phytoplankton. Elsevier Publishers, New York, p 257-262

Berta A, Sumich JL (1999) Marine mammals: evolutionary biology. Academic Press, San Diego, CA

Bricelj MV, Shumway SE (1998) Paralytic shellfish toxins in bivalve molluscs: occurrrence, transfer kinetics, and biotransformation. In: Stickney RR (ed) Rev Fish Sci 6(4): 315-383

Brower LP (1984) Chemical defense in butterflies. In: VaneWright RI, Ackery PR (eds) The biology of butterflies. Princeton University Press, Princeton, NJ, p 109-134

Brower LP, Calvert WH (1985) Foraging dynamics of bird predators on overwintering monarch butterflies in Mexico. Evolution 39:852-868

Brower LP, Fink LS (1985) A natural toxic defense system: cardenolides in butterflies versus birds. Ann NY Acad Sci 443:171-188

Brower LP, Glazier SC (1975) Localization of heart poisons in the monarch butterfly. Science 188:19-25

Brower LP, Nelson CJ, Seiber JN, Fink LS, Bond C (1988) Exaptation as an alternative to coevolution in the cardenolide-based chemical defense of monarch butterflies (Danaus plexippus L.) against avian predators. In: Spencer $\mathrm{K}$ (ed) Chemical mediation of coevolution. Academic Press, San Diego, p 447-475

Calvert W, Hedrick LE, Brower LP (1979) Mortality of the monarch butterfly (Danaus plexippus L.): avian predation at five overwinter sites in Mexico. Science 204:847-851

Coulson JC, Potts GR, Deans IR, Fraser SM (1968) Exceptional mortality of shags and other seabirds caused by paralytic shellfish poison. Br Birds 61:381-405

Culotta E (1992) Red menace in the world's oceans. Science 257:1476-1477

Duggins DO, Simenstad CA, Estes JA (1989) Magnification of secondary production by kelp detritus in coastal marine ecosystems. Science 245:170-173

Estes JA, Duggins DO (1995) Sea otters and kelp forests in
Alaska: generality and variation in a community ecological paradigm. Ecol Monogr 65:75-100

Estes JA, Tinker MT, Williams TM, Doak DF (1998) Killer whale predation on sea otters linking oceanic and nearshore ecosystems. Science 282:473-476

Fink LS, Brower LP (1981) Birds can overcome the cardenolide defense of monarch butterflies in Mexico. Nature 291: 67-70

Geraci, JR, Anderson DM, Timperi RJ, St. Aubin DJ, Early GA, Prescott JH, Mayo CA (1989) Humpback whales (Megaptera novaeangliae) fatally poisoned by dinoflagellate toxin. Can J Fish Aquat Sci 46:1895-1898

Jameson RJ (1989) Movements, home range, and territories of male sea otters off central California. Mar Mamm Sci 5: $159-172$

Keyes MC (1965) Pathology of the northern fur seal. J Am Vet Med Assoc 147:94-109

Kvitek RG (1991a) Paralytic shellfish poisoning toxins sequestered by bivalves as a defense against siphon nipping fish. Mar Biol 111:369-374

Kvitek RG (1991b) Sequestered paralytic shellfish poisoning toxins mediate Glaucous-winged gull predation on bivalve prey. Auk 108:381-392

Kvitek RG (1993) Paralytic shellfish toxins as a chemical defense in the butter clam (Saxidomus giganteus). In: Smayda TJ, Shimizu Y (eds) Toxic phytoplankton blooms in the sea. 5th Int Conf Proc Toxic Marine Phytoplankton. Elsevier, Amsterdam, p 407-412

Kvitek RG, Beitler MK (1991) Relative insensitivity of butter clam neurons to saxitoxin: a pre-adaptation for sequestering paralytic shellfish poisoning toxins as a chemical defense. Mar Ecol Prog Ser 69:47-54

Kvitek RG, Oliver JS (1992) The influence of sea otters on prey communities in southeast Alaska. Mar Ecol Prog Ser 82:103-113

Kvitek RG, DeGange AR, Beitler MK (1991) Paralytic shellfish toxins mediate sea otter food preference. Limnol Oceanogr 36:393-404

Kvitek RG, Oliver JS, DeGange AR, Anderson BS (1992) Changes in soft-bottom prey communities along a gradient in sea otter predation. Ecology 73:413-428

Kvitek RG, Bowlby CE, Steadler M (1993) The diet and foraging behavior of sea otters in southeast Alaska. Mar Mamm Sci 9:168-181

Laycock MV, Thibault P, Ayer SW, Walter JA (1994) Isolation and purification procedures for the preparation of paralytic shellfish poisoning toxin standards. Nat Toxins 2:175-183

Landsberg JH (2002) The effects of harmful algal blooms on aquatic organisms. In: Stickney RR (ed) Rev Fish Sci 10:113-390

Lefebvre KA, Powell CL, Busman M, Doucette GJ and 7 others (1999) Detection of domoic acid in northern anchovies and California sea lions associated with an unusual mortality event. Nat Toxins 7:85-92

Lefebvre KA, Dovel SL, Silver MW (2001) Tissue distribution and neurotoxic effects of domoic acid in a prominent vector species, the northern anchovy, Engraulis mordax. Mar Biol 138:693-700

Nisbet IC (1983) Paralytic shellfish poisoning: effects on breeding terns. Condor 85:338-345

Nishitani L, Chew K (1988) PSP toxins in the Pacific coast states: monitoring programs and effects on bivalve industries. J Shellfish Res 7:653-669

Ostfeld RS (1982) Foraging strategies and prey switching in the California sea otter. Oecologia 53:170-178

Paul VJ (1992a) Ecological roles of marine natural products. 
Comstock Publishing Associates, Ithaca

Paul VJ (1992b) Chemical defenses of benthic marine invertebrates. In: Paul VJ (ed) Ecological roles of marine natural products. Comstock Publishing Associates, Ithaca, p 164-188

Quayle DB (1969) Paralytic shellfish poisoning in British Columbia. Bull Fish Res Bd Can 168:1-68

Riedman ML, Estes JA (1990) The sea otter (Enhydra lutris): behavior, ecology, and natural history. US Fish Wildl Serv, Biol Rep 90(14):1-126

Scholin CA, Gulland F, Doucette GJ, Benson S and 22 others (2000) Mortality of sea lions along the central California coast linked to toxic diatom bloom. Nature 403:80-84

Shumway SE (1990) A review of the effects of algal blooms on shellfish and aquaculture. J World Aquac Soc 21:65-104

Shumway SE, Cembella AD (1993) The impact of toxic algae on scallop culture and fisheries. Rev Fish Sci 1:121-150

Shumway SE, Sherman SA, Cembella AD, Selvin R (1994) Accumulation of paralytic shellfish toxins by Atlantic surfclams, Spisula solidissima (Dillwyn, 1817) from the Gulf of Maine: seasonal changes, distribution between tissues and notes on feeding habits. Nat Toxins 2:236-251

Sierra-Beltrán A, Palafox-Uribe M, Grajales-Montiel J, CruzVillacorta A, Ochoa J (1997) Sea bird mortality at Cabo San Lucas Mexico: evidence that toxic diatom blooms are spreading. Toxicon 35:447-553

Smayda T (1992) Global epidemic of noxious phytoplankton blooms and food chain consequences in large ecosystems. In: Alexander Sherman KLM, Gold BD (eds) Food chains,

Editorial responsibility: Otto Kinne (Editor), Oldendorf/Luhe, Germany yields, models, and management of large ecosystems. Westview Press, Boulder, p 275-307

Smayda T (1997) Bloom dynamics: physiology, behaviour, trophic effects. Limnol Oceanogr 42:1132-1136

Steinberg PD, Estes JA, Winter FC (1995) Evolutionary consequences of food chain length in kelp forest communities. Science 92:8145-8148

Turner JT, Tester PA (1997) Toxic marine phytoplankton, zooplankton grazers, and pelagic food webs. Limnol Oceanogr 42:1203-1214

Van Dolah FM (2000) Marine algal toxins: origins, health effects, and their increased occurrence. Environ Health Perspect 108 (Suppl 1):133-141

Van Dolah FM, Roelke D, Greene RM (2001) Health and ecological impacts of harmful algal blooms: risk assessment needs. Human Ecol Risk Assess 7(5): 1329-1345

White AW (1980) Recurrence of kills of Atlantic herring (Clupea harengus harengus) caused by dinoflagellate toxins transferred through herbivorous zooplankton. Can J Fish Aquat Sci 37:2262-2265

White AW (1981) Marine zooplankton can accumulate and retain dinoflagellate toxins and cause fish kills. Limnol Oceanogr 26:103-109

Work TM, Barr B, Beale AM, Fritz L, Quilliam MA, Wright JLC (1993) Epidemiology of domoic acid poisoning in brown pelicans (Pelecanus occidentalis) and Brant's cormorants (Phalacrocorax penicillatus) in California. J Zool Wildl Med 24:54-62

Submitted: October 8, 2003; Accepted: January 15, 2004 Proofs received from author(s): March 22, 2004 